\title{
Prevention of chronic pain after surgery: new insights for future research and patient care
}

\author{
Ian Gilron, MD • Henrik Kehlet, MD, PhD
}

Received: 11 June 2013/Accepted: 22 October 2013/Published online: 12 November 2013

(C) Canadian Anesthesiologists' Society 2013

Management of acute pain following surgery is a vital effort that involves safely alleviating pain, nausea/vomiting, anxiety/depression, and other disabling symptoms as well as minimizing pain-related organ system dysfunction and promoting recovery. ${ }^{1}$ Various interventions, including opioids, cyclooxygenase inhibitors, local anesthetics and other classes of agents, have been proven effective in relieving pain early after surgery. ${ }^{2}$ Previous dogma that "acute" pain is always short-lived and related only to peripheral inflammatory changes at the injured site has been progressively challenged over the past 30 years. $^{3-5}$ Mounting evidence that tissue injury often results in changes to nervous system function has provided a new understanding of mechanisms that explain how surgery can often lead to chronic pain. ${ }^{6,7}$ Reported associations between the severity of preoperative and early postoperative pain and increased likelihood of transition to chronic pain ${ }^{8}$ have generated a number of research questions, for example: 1) Does more successful acute pain treatment prevent chronic pain? 2) Which other factors - that are associated with more severe early pain - are also associated with transition to chronic pain? 3) Can we preoperatively predict those patients at risk for high intensity, early, and persistent postoperative pain? Anesthesiologists, together with other health professionals, have been uniquely positioned to

\section{Gilron, MD ( $\square)$}

Departments of Anesthesiology \& Perioperative Medicine and Biomedical \& Molecular Sciences, Queen's University, Kingston General Hospital, 76 Stuart Street, Kingston,

ON K7L 2V7, Canada

e-mail: gilroni@queensu.ca

H. Kehlet, MD, PhD

Section for Surgical Pathophysiology, Rigshospitalet

Copenhagen University, Copenhagen, Denmark address these hypotheses with the ultimate goals of improving pain management and, furthermore, preventing chronic pain.

\section{Transition to chronic pain}

Chronic pain - one of the most common reasons to visit a physician - affects approximately one-quarter of the population and can be explained by a previous injury or surgery in as many as $40 \%$ of patients attending a chronic pain clinic. ${ }^{9,10}$ It is critical to recognize that a patient may report persistent pain (e.g., beyond two to three months) after surgery in several very different situations: 1) if the patient was previously pain free but has now developed a new chronic pain syndrome; 2) if previous pain at the site of surgery (e.g. low back, hip, knee) still remains; or 3) if the patient previously suffered from a chronic pain syndrome - unrelated to the surgery - and the pain persists. As with any complaint of persistent pain, a patient presenting at any time following surgery requires a careful clinical evaluation of history, physical examination, and appropriate special tests in order to identify/exclude reversible underlying conditions. The scenario of greatest concern here is that of the patient who was previously pain free and now has a disabling chronic pain condition that otherwise appears to be related to the surgery, i.e., with no reversible underlying cause. This enigmatic "transition to chronic pain" has been the focus of much research as will be discussed.

It is critical to appreciate that the incidence of transition to chronic pain and likely the predominant mechanisms underlying the transition differ according to the type of surgical procedure. ${ }^{6,11}$ Nevertheless, generally speaking, mechanistic changes that underlie development of chronic 
pain may include: 1) development of ectopic nerve discharges (e.g., due to neuroma formation at the injured site); 2) peripheral nociceptor sensitization at the site of injury; 3) central neuronal sensitization at spinal and supraspinal sites subserving the injured area; 4) central nervous system inflammatory changes triggered by injuryinduced proliferation of immunologically active microglia and astrocytes; 5) reactive and/or compensatory musculoskeletal changes following surgery (e.g., frozen shoulder or lymphedema following breast cancer surgery); 6) impaired nociceptive inhibitory modulation; and 7) enhanced nociceptive facilitory modulation. ${ }^{7}$ Given that nociceptive modulation by inhibitory and facilitory pathways is closely associated with "mind-body" interactions, understanding the impact of psychosocial factors on chronic pain after surgery requires careful attention. ${ }^{12,13}$ For example, evidence that depressed mood is associated with impaired "diffuse noxious inhibitory control" (endogenous inhibition of pain from one noxious stimulus by a second noxious stimulus) illustrates how psychological conditions, such as depression and anxiety, could play a contributory role in the persistence of pain after postsurgical tissue healing. ${ }^{14}$

\section{Can chronic pain be prevented?}

Applying traditional concepts of disease prevention to chronic pain entails classification according to: primary prevention (e.g., avoid surgery when possible, modify surgical procedure - see below); secondary prevention (e.g., early postsurgical interventions to prevent transition to chronic pain); and tertiary prevention (e.g., treat chronic pain once it has developed). Given that the majority of surgeries are unavoidable and it is very difficult to treat chronic pain once it has developed, the prospect of developing secondary prevention interventions for implementation early after surgery and of generating modified surgical techniques has spawned much research into chronic pain prevention.

\section{Regional analgesic techniques}

Previous small quasi-experimental investigations provided early data to suggest that perioperatively administered regional analgesia with local anesthetics and other agents targeted towards the site of surgery - could possibly reduce the incidence of persistent pain. This has generated much enthusiasm which led to several dozen studies evaluating the impact of regional analgesic techniques on chronic postsurgical pain. Twenty-three double-blind randomized controlled trials (RCTs) were included in a recent Cochrane systematic review of regional local anesthetics for postsurgical chronic pain prevention. ${ }^{15}$ In this review, the studies assessing pain outcomes at six and/or 12 months after surgery were considerably diverse. The vast majority of studies each focused on one specific surgical procedure; however, 11 different procedures were represented in the 23 studies. Further diversity of these studies was reflected in the route of administration of regional analgesia, including epidural, paravertebral, local/ wound infiltration, plexus/peripheral nerve block, and spinal local anesthetic administration. Despite the diversity of studies in this review, the authors were able to pool three thoracotomy-epidural trials (250 participants in total) and reported a significantly lower incidence of pain at six months with epidural analgesia (60/156) vs placebo controls (61/94). Furthermore, two breast cancer surgery-paravertebral block trials (89 participants) were pooled, again resulting in a significantly lower incidence of pain at six months with paravertebral block (10/45) vs placebo controls (19/44). As the authors appropriately acknowledged, included studies were limited by small size, potential for bias (incomplete outcome data - attrition bias, in particular), and inadequate safety reporting. Therefore, while somewhat promising, available studies are not yet sufficient to generate sound clinical recommendations for regional analgesia for the specific goal of preventing chronic postsurgical pain.

\section{Systemic drug interventions}

The multiplicity of sites of altered nociceptive modulation where transition to chronic pain may be mediated provides a rationale for evaluating the impact of systemic drug interventions on the development of chronic postsurgical pain. Thus, in parallel with the abovementioned regional analgesia studies, many other perioperative clinical trials of systemic drugs have similarly assessed pain at three to 12 months after surgery. In a recent Cochrane systematic review, ${ }^{16}$ we evaluated over 100 studies of systemically administered drugs; 40 studies included in the review were doubleblind randomized placebo-controlled trials, and 24 studies were pooled in various meta-analyses. Similar to the regional analgesia studies discussed above, substantial trial heterogeneity was observed. Study drugs - as well as dose and treatment duration - varied considerably and included intravenous ketamine (14 RCTs), oral gabapentin (ten RCTs), oral pregabalin (five RCTs), nonsteroidal anti-inflammatories (three RCTs), intravenous steroids (three RCTs), oral N-Methyl-D-aspartate (NMDA) blockers (three RCTs), oral mexiletine (two RCTs), and other agents (four RCTs). Trial settings also included a variety of different surgical procedures, including breast 
surgery (ten RCTs), hip or knee arthroplasty (six RCTs), abdominal/pelvic surgery (five RCTs), limb amputation (four RCTs), thoracotomy (three RCTs), cardiac surgery (three RCTs), spinal surgery (two RCTs), thyroidectomy (two RCTs), and other procedures (five RCTs). Despite the diversity of studies in this review, we were able to pool 1) five ketamine RCTs (reporting any pain $>0$ at three months), which showed no significant difference overall between ketamine and placebo ${ }^{16}$; 2) eight ketamine RCTs (reporting any pain $>0$ at six months) involving various different procedures, which showed a significant difference overall favouring a lower chronic pain incidence with ketamine (55/285) vs placebo (79/ $231)^{16}$; 3) five gabapentin RCTs (reporting any pain $>0$ at three months) which failed to show any significant difference overall between gabapentin and placebo; and 4) five pregabalin RCTs (reporting any pain $>0$ at three months), which showed a small statistically significant difference overall favouring a lower chronic pain incidence with pregabalin (48/217) vs placebo (70/ 222). ${ }^{16}$ Nevertheless, this last pregabalin meta-analysis was associated with substantial statistical heterogeneity and, furthermore, did not include as yet unpublished larger industry-sponsored RCTs that appear to have negative results (e.g., see www.clinicaltrials.gov trial numbers NCT00468845 and NCT00551135). Taken together, the results of this broad systematic review do not provide strong evidence for preventive effects of any of the studied agents, although some promising results with ketamine were observed. In the case of gabapentin and pregabalin, the conclusions of our Cochrane review ${ }^{16}$ are considerably less optimistic than those of a different systematic review of gabapentin and pregabalin published in 2012. ${ }^{17}$ Relevant features in that review which may account for the more negative conclusions in our Cochrane review include: 1) greater heterogeneity by combining studies (in the same meta-analysis of gabapentin and pregabalin) across different time points and pain assessment methods (e.g., different pain intensity measures and even a composite neuropathic pain scale); 2) an unexplained omission of an important negative gabapentin trial; and 3) inclusion of a positive "gabapentin" trial that incorporated co-administration of local anesthetics together with gabapentin in the intervention arm only. ${ }^{17}$ In any case, there are a number of issues in this research area to address in future studies, for example: 1) Chronic pain after which surgical procedures is most likely to be preventable with drug therapy? and 2) What is the necessary combination, dose and duration of drug therapy to see a preventive effect? - given that a single modality analgesic intervention may have little chance of success in the multifactorial pre- and postoperative nociceptive pathophysiology.
Modified surgical techniques

Since intraoperative nerve injury is a major pathogenic factor for persistent postsurgical pain, ${ }^{7,12}$ all efforts should be made for surgeons to provide nerve-sparing surgery. Such efforts have been successful in inguinal hernia surgery by using a laparoscopic technique, lightweight meshes, nontraumatic mesh fixation techniques, and intraoperative nerve identification. ${ }^{18}$ In open thoracotomy, it is well recognized that intercostal nerve injury is common with significant consequences of persistent pain. ${ }^{19,20}$ Although various efforts have been made to reduce nerve injury following rib retraction, they have not had a meaningful impact on persistent pain. In contrast, the development of video-assisted lung resection (thoracic surgery) may play a future important role in the reduction of persistent pain after thoracic surgery, ${ }^{20,21}$ as this technique avoids major rib retraction. This topic calls for future large-scale detailed studies. In breast cancer surgery, multiple factors may determine the risk of persistent pain, including intercostobrachial nerve damage, the extent of the surgical procedure, and radio- and chemotherapy. ${ }^{22}$ More detailed studies are required in nerve-sparing techniques with axillary dissection. In other operations with significant persistent postsurgical pain, such as major gynecological procedures and joint arthroplasty, future detailed studies are required to document the effect of minimal invasive nervesparing techniques $v s$ other risk factors (psychosocial, inflammation, etc.).

\section{Clinical needs and research opportunities}

Current trends suggest a growing need for surgical procedures - related largely to the increasing risk of cancer in aging populations - that are associated with a substantial risk of chronic postsurgical pain. ${ }^{23}$ Research conducted over the past 30 years has provided many important insights into risk factors and potential prevention strategies for persistent postsurgical pain. Indeed, we have learned from scores of laboratory and human intervention studies that the substantial complexity of pathophysiological changes leading to chronic postsurgical pain makes the quest for prevention strategies particularly challenging.

\section{Perioperative clinical assessment}

Although a highly successful intervention for preventing chronic pain after surgery has not yet been identified, research to date has taught us some important lessons about the importance of a clinical evaluative approach to assessing persistent pain after surgery - for both research and clinical purposes. As illustrated in the Figure, assessing 
Figure Overarching framework for the assessment of persistent postsurgical pain and relevant perioperative factors for patient care and research

Figure Cadre global pour l'évaluation de la douleur postchirurgicale persistante et facteurs périopératoires pertinents pour les soins aux patients et la recherche

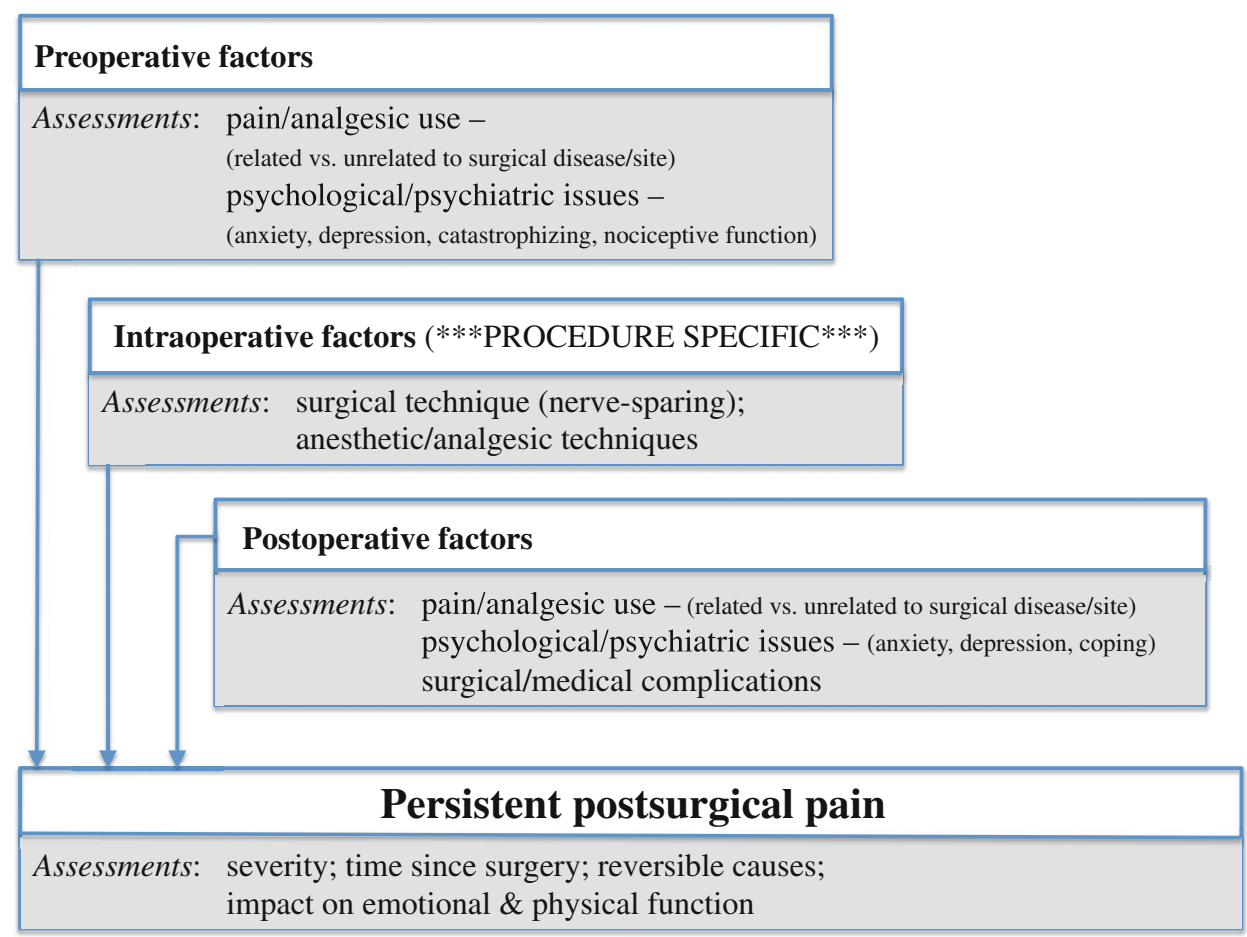

persistent postsurgical pain, both in clinical practice and in research studies, requires careful attention to the time period since surgery, the severity and reversible causes of the pain, and the impact on analgesic use as well as on emotional and physical functioning. ${ }^{24}$ Given obvious differences in anatomical regions, degree of tissue injury, and underlying surgical disease, evidence points to the need for conducting assessments of persistent postoperative pain in a procedure-specific fashion. ${ }^{25,26}$ Furthermore, mounting evidence suggests that various preoperative factors (e.g., preexisting pain, psychological/psychiatric comorbidities) are associated with a greater risk of persistent postsurgical pain. ${ }^{14,27}$ In this context, a genetic disposition for being a high-risk pain responder and at risk for persistent pain is currently receiving much attention. $^{28,29}$ At this time, various other techniques with preoperative nociceptive stimulation to predict high-pain responders have been described ${ }^{30}$ and may be of future use to allocate high-risk pain patients to more intensive postoperative pain therapy. Thus, while assessment, identification, and occasional stratification of these preoperative factors are critical for well-designed, observational, and interventional studies, it is also important for clinicians to monitor higher-risk patients much more closely in the postoperative period. Intraoperative factors are of central importance to the development of chronic postsurgical pain. The type of surgical procedure and the specific surgical technique which are associated with the likelihood and magnitude of surgical nerve injury - require careful consideration in both research and clinical settings. Results from future clinical trials are anticipated to provide further guidance on the selection of optimal surgical techniques associated with lower rates of persistent postsurgical pain. Finally, the postoperative period requires the most intensive level of clinical assessment and patient care. This involves ongoing assessment of pain - both at rest and with movement, ${ }^{31}$ administration and monitoring of analgesic treatments (related $v s$ unrelated to surgical disease/site), and the evaluation and management of surgical $/$ medical complications and ongoing psychological/psychiatric issues (e.g., anxiety, depression, coping).

\section{Study design issues}

Deliberation on chronic pain prevention studies conducted to date has provided some insight into factors related to the clinical importance of study outcomes. Such factors include the magnitude of the reduction in incidence, intensity, or duration of pain; the safety/tolerability of the preventive intervention; and the impact of the intervention on pain-related secondary outcomes, such as mood, physical function, and quality of life. ${ }^{32}$ Among these factors, the primary outcome must be clinically relevant (e.g. the incidence of daily moderate-severe persistent pain at six months or later following surgery), and the trial must be statistically powered such that trial methods can detect a clinically important difference between the trial interventions. Thus, various features of the trial setting and study intervention may dictate the need for 
considerably detailed and sizeable studies, including preintra- and postoperative patient demographics ${ }^{24,33}$ and, therefore, probably multicentre trials. Another important feature of prevention trials that impacts cost as well as interpretation is the need for patient follow-up to clinically important time points, e.g., six and/or 12 months following surgery. The added length of such trials clearly adds to the expense; moreover, the cumulative risk of losing participants to follow-up provides a problematic source of attrition bias, ${ }^{34}$ since the nature of the outcome (regarding persistent pain) in study dropouts may be associated with their withdrawal from the study.

Is it time for a different prevention paradigm?

Given previous observations that more intense early postoperative pain is associated with a higher risk of chronic pain after surgery, it is understandable that many studies - with disappointing results thus far - have evaluated the preventive efficacy of analgesic therapies administered in the early postoperative period. Since neuropathic pain is predominant, ${ }^{7,12}$ intense focus must continue on reducing intraoperative nerve damage. Nevertheless, it is also quite possible that entirely different classes of neuroactive agents - which do not necessarily show analgesic efficacy but which suppress specific operant mechanisms of transition to chronic pain may be useful in preventing chronic pain after surgery. For example, several different neurotrophic factors (e.g., recombinant human brain-derived neurotrophic factor rhBDNF), neuroprotective agents (e.g., acetyl-L-carnitine), and antioxidants (e.g., alpha-lipoic acid) have shown some promising results in clinical trials of neuropathic conditions where pain has been longstanding. ${ }^{35}$ In recent years, the role of neuroinflammatory mechanisms, including microglial activation to generate neuropathic pain, has received much attention. ${ }^{36} \mathrm{~A}$ recent example of attempts to prevent chronic pain with a "non-analgesic" intervention comes from a placebo-controlled trial of oral minocycline an inhibitor of microglial activation expected to suppress central sensitization - administered for eight days perioperatively in lumbar discectomy patients. $^{37}$ Unfortunately, minocycline did not produce significant pain reductions at three months postoperatively; however, since all patients had pain prior to surgery, it must be acknowledged that this trial was conducted in likely the most challenging population for prevention. ${ }^{37}$ It is possible that such neuroprotective agents may show even more impressive preventive efficacy when administered perioperatively to patients with no preexisting pain. These concepts provide new opportunities for research and treatment with different classes of potentially preventive interventions.

\section{Conclusion}

A remarkable amount of work carried out over the past 30 years has greatly advanced our understanding of the mechanisms and clinical features of chronic postsurgical pain. Although perioperative preventive intervention studies have thus far been largely disappointing, some promising signals from relatively small RCTs of regionally administered local anesthetics and systemic ketamine suggest the possibility that postsurgical transition to chronic pain can be suppressed, if not completely abolished. Retrospective consideration of research conducted to date provides insight into the future need for: 1) procedure-specific investigations, 2) careful assessment of various critical pre- intra- and postoperative factors for clinical care and their incorporation into the design of prevention trials, and 3) specific definitions of outcome measures to facilitate presenting the clinically relevant effects of interventions. Finally, a continued collaborative bench-to-bedside approach to research is crucial so that new biological insight into the pathogenesis of chronic postsurgical pain can guide the development of more effective prevention strategies.

\section{La prévention de la douleur chronique après chirurgie : nouvelles réflexions pour la recherche future et pour les soins aux patients}

La prise en charge de la douleur aiguë suivant une chirurgie est une phase cruciale qui comprend non seulement le soulagement sécuritaire de la douleur, des nausées et vomissements, de l'anxiété, de la dépression et d'autres symptômes invalidants, mais aussi la minimisation des dysfonctionnements systémiques des organes et la promotion du rétablissement. ${ }^{1}$ Il a été démontré que diverses interventions, notamment les opiö̈des, les inhibiteurs de la cyclo-oxygénase, les anesthésiques locaux et d'autres classes d'agents, étaient efficaces pour soulager rapidement la douleur après une chirurgie. ${ }^{2}$ L'ancien dogme selon lequel la douleur « aiguë » était toujours de courte durée et liée seulement aux changements inflammatoires périphériques au site lésé a eu la vie de plus en plus dure au cours des 30 dernières années. ${ }^{3-5}$ Les données probantes attestant que les lésions tissulaires entraînent souvent des changements au niveau du fonctionnement du système nerveux s'accumulent, et nous développons une nouvelle compréhension des mécanismes expliquant comment une chirurgie peut 
souvent provoquer une douleur chronique., ${ }^{6,7}$ Les associations rapportées entre gravité de la douleur préopératoire et postopératoire précoce et augmentation de la probabilité de transition vers une douleur chronique ${ }^{8}$ ont attisé plusieurs questions de recherche, notamment : 1) Peut-on prévenir la douleur chronique avec un meilleur soulagement de la douleur aiguë? 2) Quels autres facteurs - associés à une douleur précoce plus grave - sont également associés à une transition vers une douleur chronique? 3) Peut-on prévoir, en préopératoire, quels patients seront à risque de douleur postopératoire d'intensité élevée, précoce et persistante? Les anesthésiologistes, de concert avec d'autres professionnels de la santé, se sont trouvés dans une position privilégiée pour s'atteler à ces questions avec l'objectif ultime d'améliorer la prise en charge de la douleur et de prévenir la douleur chronique.

\section{La transition vers une douleur chronique}

La douleur chronique est l'une des principales causes de visite chez le médecin et touche environ un quart de la population. Elle peut s'expliquer par une lésion ou une chirurgie antérieure chez près de $40 \%$ des patients se rendant dans une clinique de douleur chronique. ${ }^{9,10}$ Il est essentiel de savoir qu'un patient peut faire état de douleur persistante (par ex., au delà de deux ou trois mois) après une chirurgie dans des situations très différentes : 1) le patient ne souffrait pas de douleur auparavant mais souffre désormais d'un nouveau syndrome de douleur chronique; 2) la douleur présente avant l'opération au site de la chirurgie (par ex. bas du dos, hanche, genou) persiste; ou 3) le patient souffrait précédemment d'un syndrome de douleur chronique - non lié à la chirurgie - et la douleur persiste. Tout comme avec n'importe quelle plainte de douleur persistante, lorsqu'un patient se présente à quelque moment que ce soit après une chirurgie, il convient de procéder à une évaluation clinique minutieuse de ses antécédents, à un examen physique et de réaliser les tests spéciaux indiqués afin d'identifier ou d'exclure toute condition sous-jacente réversible. Le cas le plus inquiétant ici est celui du patient qui n'avait aucune douleur auparavant mais qui présente désormais une douleur chronique invalidante qui semble autrement liée à la chirurgie - donc sans cause sous-jacente réversible. Cette «transition vers une douleur chronique » énigmatique a fait l'objet de nombre de recherches, comme nous en discuterons ci-dessous.

Il est essentiel de réaliser que l'incidence de transition vers une douleur chronique et, probablement, les mécanismes prédominants sous-jacents à la transition, sont différents selon le type d'intervention chirurgicale. $^{6,11}$ Ceci étant dit, en règle générale, les changements mécanistes sous-jacents à l'apparition d'une douleur chronique peuvent comprendre : 1) l'apparition de décharges ectopiques (par ex., en raison de la formation d'un névrome au site lésé); 2) une sensibilisation nociceptive périphérique au site de la lésion; 3) une sensibilisation neuronale centrale aux sites rachidiens et cérébraux desservant la zone lésée; 4) des changements inflammatoires dans le système nerveux central déclenchés par la prolifération, induite par la lésion, de microglies et d'astrocytes immunologiquement actifs; 5) des changements musculosquelettiques réactifs et/ou compensatoires après une chirurgie (par ex. une épaule immobilisée ou un lymphoedème après une chirurgie de cancer du sein); 6) une réduction de la modulation inhibitrice nociceptive; et 7) une augmentation de la modulation facilitatrice nociceptive. ${ }^{7}$ Étant donné que la modulation nociceptive par les voies inhibitrices et facilitatrices est en étroite association avec les interactions « corps-esprit», il convient de porter une attention particulière à la compréhension de l'impact de facteurs psychosociaux sur la douleur chronique après une chirurgie. $^{12,13}$ Par exemple, il existe des données probantes soutenant qu'une humeur déprimée est associée à un moins bon « contrôle inhibiteur diffus induit par la nociception » (l'inhibition endogène de la douleur d'un stimulus nociceptif par un autre stimulus nociceptif). Cela illustre la façon dont les états psychologiques tels que la dépression et l'anxiété pourraient contribuer à la persistance de la douleur après la guérison postchirurgicale des tissus. ${ }^{14}$

\section{Peut-on prévenir la douleur chronique?}

L'application des concepts traditionnels de prévention des maladies à la douleur chronique implique une classification se fondant sur : la prévention primaire (par ex., éviter la chirurgie lorsque possible, modifier l'intervention chirurgicale - voir ci-dessous); la prévention secondaire (par ex., les interventions postchirurgicales précoces pour prévenir la transition vers une douleur chronique); et la prévention tertiaire (par ex., le traitement de la douleur chronique une fois qu'elle est apparue). Comme la majorité des chirurgies sont inévitables et qu'il est très difficile de traiter la douleur chronique une fois qu'elle est apparue, l'espoir de mettre au point des interventions de prévention secondaire à mettre en œuvre rapidement après la chirurgie et de créer des techniques chirurgicales modifiées a motivé de nombreuses recherches en prévention de la douleur chronique.

Les techniques d'analgésie locorégionale

Des données anciennes tirées d'études de petite envergure et quasi-expérimentales réalisées par le passé suggèrent 
qu'une analgésie locorégionale à base d'anesthésiques locaux et d'autres agents, administrée en périopératoire et ciblant le site de la chirurgie, pourrait possiblement réduire l'incidence de douleur persistante. Ces résultats ont suscité beaucoup d'enthousiasme et la réalisation de plusieurs dizaines d'études évaluant l'impact des techniques d'analgésie régionale sur la douleur chronique postchirurgicale. Une revue méthodique récente de la base de données Cochrane a tiré 23 études randomisées contrôlées (ERC) à double insu s'intéressant à l'utilisation d'anesthésiques locaux pour la prévention de la douleur chronique postchirurgicale. ${ }^{15}$ Dans cette revue, les études évaluant les pronostics de douleur à six et/ou 12 mois post-chirurgie étaient très diverses. La vaste majorité des études se concentrait chacune sur une intervention chirurgicale en particulier; toutefois, 11 interventions différentes étaient représentées dans les 23 études. La diversité de ces études se reflétait également dans la voie d'administration de l'analgésie locorégionale, avec notamment l'administration péridurale, paravertébrale, locale / au site de la lésion, plexique / au nerf périphérique et rachidienne d'anesthésiques locaux. Malgré la diversité des études incluses dans cette revue méthodique, les auteurs ont réussi à réunir les données de trois études portant sur des péridurales pour thoracotomie (250 participants au total) et ont rapporté une incidence significativement plus faible de douleur à six mois avec une analgésie péridurale (60/156) vs. le groupe témoin (61/94). En outre, deux études examinant les blocs paravertébraux lors de chirurgies pour le cancer du sein (89 participantes) ont été colligées, et les auteurs ont là aussi pu observer une incidence significativement plus faible de douleur à six mois avec un bloc paravertébral (10/45) vs. les groupes témoin (19/44). Toutefois, comme les auteurs le reconnaissent, les études incluses dans cette revue méthodique étaient limitées de par leur petite taille, le potentiel de biais (données de pronostic incomplètes - biais d'attrition, en particulier), et une mauvaise description de l'innocuité. Par conséquent, bien qu'elles soient, dans une certaine mesure, prometteuses, les études disponibles ne suffisent pas encore pour émettre des directives cliniques avisées concernant l'utilisation de l'analgésie régionale avec l'objectif spécifique de prévenir la douleur chronique postchirurgicale.

Les interventions médicamenteuses systémiques

En raison de la multiplicité des sites de modulation modifiée de la nociception où il peut y avoir une transition vers la douleur chronique, on doit évaluer l'impact des interventions médicamenteuses systémiques sur l'évolution de la douleur chronique postchirurgicale. C'est pourquoi, parallèlement aux études d'analgésie régionale mentionnées ci-dessus, de nombreuses autres études cliniques périopératoires portant sur les médicaments systémiques ont aussi évalué la douleur de trois à 12 mois après une chirurgie. Dans une revue méthodique récente de la base de données Cochrane, ${ }^{16}$ nous avons évalué plus de 100 études portant sur des médicaments administrés par voie systémique; 40 études comprises dans cette revue étaient des études randomisées à double insu et contrôlées par placebo, et 24 ont été colligées dans diverses méta-analyses. Tout comme dans le cas des études d'analgésie régionale discutées ci-dessus, il existait une hétérogénéité considérable entre les études. Les médicaments à l'étude - ainsi que la posologie et la durée de traitement - variaient considérablement et incluaient notamment: la kétamine (14 ERC), la gabapentine par voie orale (dix ERC), la prégabaline par voie orale (cinq ERC), les anti-inflammatoires non stéroïdiens (trois ERC), les stéroïdes par voie intraveineuse (trois ERC), les bloqueurs du $N$-méthyl-D-aspartate (NMDA) par voie orale (trois ERC), la mexilétine (deux ERC) et d'autres agents (quatre ERC). Les contextes d'études comprenaient également toutes sortes d'interventions chirurgicales, dont des chirurgies thoraciques (dix ERC), des arthroplasties de la hanche ou du genou (six ERC), des chirurgies abdominales ou pelviennes (cinq ERC), des amputations de membres (quatre ERC), des thoracotomies (trois ERC), des chirurgies cardiaques (trois ERC), des chirurgies de la colonne (deux ERC), des thyroïdectomies (deux ERC) et d'autres interventions (cinq ERC). Malgré l'hétérogénéité des études comprises dans cette revue, nous sommes parvenus à regrouper 1) cinq ERC sur la kétamine (rapportant toute douleur $>0$ à trois mois), qui n'ont montré aucune différence globale significative entre la kétamine et le placebo ${ }^{16}$; 2) huit ERC sur la kétamine (rapportant toute douleur $>0$ à six mois) utilisée dans le cadre de diverses interventions, qui ont montré une différence globale significative entre la kétamine et le placebo, soit une incidence plus faible de douleur chronique avec la kétamine $(55 / 285)$ qu'avec le placebo $(79 / 231)^{16}$; cinq études sur la gabapentine (rapportant toute douleur $>0$ à trois mois) qui n'ont pas montré de différence globale significative entre la gabapentine et le placebo; et 4) cinq ERC sur la prégabaline (rapportant toute douleur $>0$ à trois mois), qui ont montré une petite différence globale significative d'un point de vue statistique, soit une incidence plus faible de douleur chronique avec la prégabaline (48/217) qu'avec le placebo (70/222) ${ }^{16}$ Cependant, cette dernière méta-analyse sur la prégabaline a été associée à une hétérogénéité statistique considérable, en plus de ne pas inclure d'autres ERC de plus grande envergure financées par l'industrie et non encore publiées qui semblent avoir des résultats négatifs (par ex., voir www.clinicaltrials.gov nos. NCT00468845 et NCT00551135). 
Dans l'ensemble, les résultats de cette vaste revue méthodique n'offrent pas de données probantes solides quant aux effets de prévention des agents étudiés, bien que certains résultats prometteurs aient été observés avec la kétamine. Dans le cas de la gabapentine et de la prégabaline, les conclusions de notre revue de la base de données Cochrane sont considérablement moins optimistes que celles d'une autre revue méthodique de la gabapentine et de la prégabaline publiée en $2012 .{ }^{17}$ Voici certaines des caractéristiques pertinentes de cette autre revue qui pourraient expliquer nos conclusions plus pessimistes : 1) une plus grande hétérogénéité, en raison de la combinaison d'études (dans la même méta-analyse de la gabapentine et de la prégabaline) examinant différents points dans le temps et différentes méthodes d'évaluation de la douleur (par ex., différentes mesures de l'intensité de la douleur et même une échelle composite de la douleur neuropathique); 2) l'omission inexpliquée d'une importante étude négative sur la gabapentine; et 3) l'inclusion d'une étude positive sur la 'gabapentine' incorporant l'administration concomitante d'anesthésiques locaux dans le groupe intervention seulement. ${ }^{17}$ Dans tous les cas, plusieurs questions dans ce domaine de recherche devront être abordées dans les études à venir, notamment : 1) il est fort probable qu'un traitement médicamenteux préviendra la douleur chronique lorsqu'il est administré après certains types d'interventions chirurgicales, et des recherches supplémentaires peuvent contribuer à l'identification de ces interventions; 2) quelle combinaison, quelle dose et quelle durée de traitement médicamenteux sont nécessaires pour avoir un effet préventif - en tenant compte du fait qu'une intervention analgésique unimodale aura peu de chances de succès avec une physiopathologie nociceptive pré- et postopératoire multifactorielle?

\section{Les techniques chirurgicales modifiées}

Étant donné que les lésions nerveuses peropératoires sont un facteur pathogénique important de douleur postchirurgicale persistante, tous les efforts doivent être faits afin que les chirurgiens offrent une chirurgie qui épargne au maximum les nerfs. De tels efforts ont eu du succès dans le cadre de chirurgies d'hernie inguinale réalisées grâce à une technique par laparoscopie, des treillis chirurgicaux légers, des techniques de fixation du treillis chirurgical non traumatiques et l'identification peropératoire des nerfs. ${ }^{18}$ Dans les cas de thoracotomie ouverte, les lésions des nerfs intercostaux sont courantes et entraînent d'importantes conséquences en matière de douleur persistante. ${ }^{19,20}$ Malgré les divers efforts déployés pour réduire les lésions nerveuses après l'écartement des côtes, aucun n'a eu d'impact significatif sur la douleur persistante. Par contre, la mise au point de la technique de résection pulmonaire assistée par vidéo (chirurgie thoracique) pourrait à l'avenir jouer un rôle important pour réduire la douleur persistante après une chirurgie thoracique, ${ }^{20,21}$ étant donné que cette technique permet de ne pas trop écarter les côtes. Ce sujet nécessite la réalisation d'autres études détaillées et d'envergure importante. Dans les cas de chirurgies de cancer du sein, de nombreux facteurs peuvent déterminer le risque de douleur persistante, notamment les lésions aux nerfs intercostobrachiaux, l'étendue de l'intervention chirurgicale, ainsi que la radio- et la chimiothérapie. ${ }^{22}$ Des études plus détaillées sont nécessaires pour explorer les techniques épargnant les nerfs lors d'une dissection axillaire. Dans le cas d'autres opérations entraînant une importante douleur postchirurgicale persistante, telles que les interventions gynécologiques majeures et les arthroplasties totales, des études détaillées sont nécessaires à l'avenir afin de documenter l'effet des techniques épargnant les nerfs et minimalement effractives par rapport à d'autres facteurs de risque (psychosociaux, inflammation, etc.).

\section{Besoins cliniques et perspectives de recherche}

On observe actuellement une augmentation de la demande pour des interventions chirurgicales - liée en grande partie au risque croissant de cancers chez les populations vieillissantes -, lesquelles sont associées à un risque considérable de douleur postchirurgicale. ${ }^{23}$ Les recherches menées au cours des 30 dernières années nous ont donné de nombreuses perspectives importantes quant aux facteurs de risque et aux stratégies de prévention potentielle de la douleur chirurgicale persistante. En effet, des dizaines d'études de laboratoires et d'interventions chez l'humain nous ont appris que l'énorme complexité des changements physiopathologiques menant à la douleur chronique postchirurgicale rend particulièrement difficile la découverte de stratégies de prévention.

\section{L'évaluation clinique périopératoire}

Bien que l'on n'ait identifié aucune intervention de prévention de la douleur chronique après une chirurgie affichant un taux de réussite très élevé, à ce jour la recherche nous a appris d'importantes leçons quant à l'importance d'une approche d'évaluation clinique qui permette d'évaluer la douleur persistante après une chirurgie - aussi bien à des fins de recherche que cliniques. Comme l'illustre notre figure, pour évaluer la douleur postchirurgicale persistante, que ce soit dans la pratique clinique ou dans les études de recherche, il convient de porter une attention particulière à l'intervalle de temps écoulé depuis la chirurgie, à la gravité et aux causes réversibles de la douleur, et à son impact sur l'utilisation d'analgésiques ainsi que sur le fonctionnement émotionnel et physique. ${ }^{24}$ Étant donné les différences évidentes entre les 
régions anatomiques, le degré de lésion tissulaire et la pathologie chirurgicale sous-jacente, les données probantes soulignent le besoin d'évaluer la douleur postopératoire persistante selon l'intervention pratiquée. ${ }^{25,26}$ En outre, des données probantes de plus en plus nombreuses laissent penser que divers facteurs préopératoires (par ex., une douleur préexistante, des comorbidités psychologiques / psychiatriques) sont associés à un risque accru de douleur postchirurgicale persistante. ${ }^{14,27}$ Dans un tel contexte, l'hypothèse qu'il existe une prédisposition génétique à courir un risque élevé de réagir à la douleur et un risque de souffrir de douleur persistante reçoit à l'heure actuelle beaucoup d'attention de la part de la communauté scientifique. ${ }^{28,29}$ Plusieurs autres techniques impliquant la stimulation nociceptive préopératoire pour identifier les personnes répondant fortement à la douleur ont déjà été décrites ${ }^{30}$ ces techniques pourraient s'avérer utiles à l'avenir pour garantir que les patients courant un risque plus élevé de souffrir de douleur reçoivent un traitement postopératoire de la douleur plus intensif. Ainsi, bien que l'évaluation, l'identification et la stratification occasionnelle de ces facteurs préopératoires soient cruciales à la réalisation d'études interventionnelles observationnelles bien conçues, il est également important que les cliniciens surveillent plus assidûment les patients à plus haut risque au cours de la période postopératoire. Les facteurs peropératoires ont une importance cruciale dans l'apparition de la douleur postchirurgicale chronique. Le type d'intervention chirurgicale et la technique chirurgicale spécifique - deux paramètres associés à la probabilité d'une lésion nerveuse et à son ampleur - doivent faire l'objet d'une attention particulière et ce, aussi bien en recherche que dans le contexte clinique. On prévoit que les résultats des études cliniques futures fourniront des pistes supplémentaires pour la sélection de techniques chirurgicales optimales associées à des taux plus bas de douleur postchirurgicale persistante. Enfin, la période postopératoire requiert le niveau le plus intensif d'évaluation clinique et de soins aux patients. Pour ce faire, il convient de procéder à une évaluation constante de la douleur - au repos et en mouvement $-{ }^{31}$ d'administrer et de surveiller les traitements analgésiques (liés $v s$. non liés à la pathologie / au site chirurgical), et d'évaluer et de prendre en charge les complications chirurgicales / médicales ainsi que les problèmes psychologiques / psychiatriques en cours (par ex., anxiété, dépression, adaptation).

\section{Problèmes de méthodologie d'étude}

Les délibérations concernant les études de prévention de la douleur chronique réalisées à ce jour ont donné quelques perspectives quant aux facteurs liés à l'importance clinique des résultats d'étude. Parmi ces facteurs, citons l'ampleur de la réduction de l'incidence, de l'intensité ou de la durée de la douleur; l'innocuité / la tolérabilité de l'intervention préventive; et l'impact de l'intervention sur les résultats secondaires liés à la douleur, comme l'humeur, le fonctionnement physique et la qualité de vie. ${ }^{32}$ Parmi ces facteurs, le critère d'évaluation principal doit être pertinent d'un point de vue clinique (par ex., l'incidence de douleur quotidienne modérée à grave à six mois ou plus après une chirurgie), et l'étude doit avoir une puissance statistique suffisante pour que les méthodes de l'étude puissent détecter toute différence importante d'un point de vue clinique entre les interventions à l'étude. Ainsi, différentes caractéristiques liées au contexte de l'étude et à l'intervention évaluée pourraient dicter la réalisation d'études considérablement détaillées et de grande envergure, notamment en matière de données démographiques des patients en pré-, per- et postopératoire $^{24,33}$ - donc, d'études probablement multicentriques. Une autre caractéristique importante des études de prévention, qui a un impact sur leur coût ainsi que sur leur interprétation, est le besoin de suivi des patients jusqu'à des points dans le temps importants d'un point de vue clinique, par ex., six et/ou 12 mois après la chirurgie. La durée prolongée de telles études a clairement un impact sur leur coût; en outre, le risque cumulé de perte de participants au suivi constitue une source problématique de biais d'attrition, ${ }^{34}$ étant donné que la nature du résultat (concernant la douleur persistante) chez les personnes perdues au suivi pourrait être associée à leur retrait de l'étude.

Le temps pour un paradigme de prévention différent est-il venu?

Étant donné les observations précédentes selon lesquelles une douleur postopératoire précoce plus intense est associée à un risque accru de douleur chronique après la chirurgie, on comprend pourquoi de nombreuses études - ayant donné des résultats décevants pour le moment - ont évalué l'efficacité de prévention de traitements analgésiques administrés au début de la période postopératoire. Au vu de la prédominance de la douleur neuropathique, ${ }^{7,12}$ il faut continuer à porter une attention particulière à la réduction des lésions nerveuses peropératoires. Toutefois, il est tout à fait possible aussi que des classes d'agents neuroactifs complètement différentes - lesquels ne montrent pas forcément d'efficacité analgésique mais qui suppriment certains mécanismes opérants spécifiques de transition vers une douleur chronique - pourraient s'avérer utiles pour prévenir la douleur chronique après une chirurgie. Par exemple, plusieurs facteurs neurotrophiques différents (par ex., le facteur neurotrophique recombinant dérivé du cerveau - rhBDNF), les agents neuroprotecteurs (par ex., 
l'acétyl-L-carnitine) et les antioxydants (par ex., l'acide alpha-lipoïque) ont affiché des résultats prometteurs dans des études cliniques sur les neuropathies où la douleur est persistante. ${ }^{35}$ Ces dernières années, le rôle des mécanismes neuro-inflammatoires, notamment celui impliquant l'activation des microglies qui produit une douleur neuropathique, a reçu beaucoup d'attention. ${ }^{36}$ Un exemple récent de tentatives de prévention de la douleur chronique à l'aide d'une intervention 'non analgésique' est tiré d'une étude contrôlée par placebo portant sur la minocycline orale - un inhibiteur de l'activation des microglies dont on prévoit qu'il supprimera la sensibilisation centrale - administrée durant huit jours avant la chirurgie chez les patients subissant une discectomie lombaire. ${ }^{37}$ Malheureusement, la minocycline n'a pas réduit de manière significative la douleur à trois mois après la chirurgie; toutefois, étant donné que tous les patients souffraient de douleur avant la chirurgie, il faut tenir compte du fait que cette étude a été menée dans la population où la prévention était probablement la plus difficile à réaliser. ${ }^{37}$ Il est possible que de tels agents neuroprotecteurs montrent une efficacité de prévention encore plus impressionnante lorsqu'ils sont administrés en périopératoire à des patients ne souffrant pas de douleur auparavant. Il s'agit là de concepts qui ouvrent de nouvelles pistes de recherche et de traitement avec différentes classes d'interventions potentiellement préventives.

\section{Conclusion}

Une quantité remarquable de travail effectué au cours des 30 dernières années a considérablement fait avancer notre compréhension des mécanismes et des caractéristiques cliniques de la douleur chronique postchirurgicale. Bien que les études portant sur des interventions périopératoires de prévention demeurent pour la plupart décevantes à l'heure actuelle, certains signes prometteurs sont apparus dans des ERC de relativement petite envergure examinant les effets d'anesthésiques locaux administrés de façon régionale et de kétamine administrée par voie systémique. Ces études suggèrent qu'il est possible que la transition postchirurgicale vers une douleur chronique puisse être supprimée, voire complètement abolie. L'examen rétrospectif des recherches menées à ce jour nous donne une perspective sur les besoins futurs en matière de recherche, soit : 1) des études portant sur une intervention en particulier; 2) l'évaluation minutieuse de divers facteurs pré-, per- et postopératoires cruciaux pour les soins cliniques et leur intégration dans la méthodologie d'études de prévention, et 3) des définitions spécifiques pour mesurer les résultats afin de faciliter la présentation des effets d'interventions pertinents d'un point de vue clinique. Enfin, une approche collaborative continue de la recherche, allant du laboratoire au chevet du patient, est essentielle. En effet, une telle approche permettra qu'une nouvelle compréhension de la biologie de la pathogenèse de la douleur chronique postchirurgicale guide la mise au point de stratégies de prévention plus efficaces.

Conflicts of interest Ian Gilron has received industry support from Pfizer, Aventis Pharma, Novopharm, PharmaScience, Apotex, MerckFrosst, Johnson \& Johnson, Ortho-McNeill, and Janssen-Ortho. He has received peer-reviewed grants from the Canadian Institutes of Health Research, the Physicians' Services Incorporated Foundation, and Queen's University. Henrik Kehlet has no conflicts of interest to declare relevant to this work.

Conflit d'intérêt Ian Gilron a reçu un soutien de l'industrie de Pfizer, Aventis Pharma, Novopharm, PharmaScience, Apotex, Merck-Frosst, Johnson \& Johnson, Ortho-McNeill et Janssen-Ortho. Il a reçu des subventions évaluées par des pairs des Instituts de recherche en santé du Canada, de la Physicians' Services Incorporated Foundation et de l'Université Queen's. Henrik Kehlet n'a pas de conflit d'intérêt pertinent à cet article à déclarer.

\section{References}

1. Kehlet H, Dahl JB. Anaesthesia, surgery, and challenges in postoperative recovery. Lancet 2003; 362: 1921-8.

2. Wu $C L$, Raja $S N$. Treatment of acute postoperative pain. Lancet 2011; 377: 2215-25.

3. Wall $P D$. The prevention of postoperative pain. Pain 1988; 33 : 289-90.

4. Perkins FM, Kehlet $H$. Chronic pain as an outcome of surgery. A review of predictive factors. Anesthesiology 2000; 93: 1123-33.

5. Macrae WA. Chronic post-surgical pain: 10 years on. $\mathrm{Br} \mathrm{J}$ Anaesth 2008; 101: 77-86.

6. Kehlet H, Jensen TS, Woolf CJ. Persistent postsurgical pain: risk factors and prevention. Lancet 2006; 367: 1618-25.

7. Deumens $R$, Steyaert A, Forget $P$, et al. Prevention of chronic postoperative pain: cellular, molecular, and clinical insights for mechanism-based treatment approaches. Prog Neurobiol 2013; 104: 1-37.

8. Katz J, Jackson M, Kavanagh BP, Sandler AN. Acute pain after thoracic surgery predicts long-term post-thoracotomy pain. Clin $\mathrm{J}$ Pain 1996; 12: 50-5.

9. Crombie IK, Davies HT, Macrae WA. Cut and thrust: antecedent surgery and trauma among patients attending a chronic pain clinic. Pain 1998; 76: 167-71.

10. Johansen A, Romundstad L, Nielsen CS, Schirmer H, Stubhaug A. Persistent postsurgical pain in a general population: prevalence and predictors in the Tromso study. Pain 2012; 153: 1390-6.

11. Haroutiunian S, Nikolajsen L, Finnerup NB, Jensen TS. The neuropathic component in persistent postsurgical pain: a systematic literature review. Pain 2013; 154: 95-102.

12. Katz, J, Seltzer Z. Transition from acute to chronic postsurgical pain: risk factors and protective factors. Expert Rev Neurother 2009; 9: 723-44.

13. Theunissen M, Peters ML, Bruce J, Gramke HF, Marcus MA. Preoperative anxiety and catastrophizing: a systematic review and meta-analysis of the association with chronic postsurgical pain. Clin J Pain 2012; 28: 819-41. 
14. de Souza JB, Potvin S, Goffaux P, Charest J, Marchand S. The deficit of pain inhibition in fibromyalgia is more pronounced in patients with comorbid depressive symptoms. Clin J Pain 2009; 25: $123-7$

15. Andreae $M H$, Andreae DA. Local anaesthetics and regional anaesthesia for preventing chronic pain after surgery. Cochrane Database Syst Rev 2012; 10: CD007105.

16. Chaparro L, Smith S, Moore RA, Wiffen PJ, Gilron I. Pharmacotherapy for the prevention of chronic pain after surgery in adults. Cochrane Database Syst Rev 2013; (7): CD008307. doi:10.1002/14651858.CD008307.pub2.

17. Clarke H, Bonin RP, Orser BA, Englesakis M, Wijeysundera DN, Katz $J$. The prevention of chronic postsurgical pain using gabapentin and pregabalin: a combined systematic review and meta-analysis. Anesth Analg 2012; 115: 428-42.

18. Kehlet H, Roumen RM, Reinpold W, Miserez M. Invited commentary: persistent pain after inguinal hernia repair: what do we know and what do we need to know? Hernia 2013; 17: 293-7.

19. Wildgaard K, Ravn J, Kehlet $H$. Chronic post-thoracotomy pain: a critical review of pathogenic mechanisms and strategies for prevention. Eur J Cardiothorac Surg 2009; 36: 170-80.

20. Wildgaard K, Ravn J, Nikolajsen L, Jakobsen E, Jensen TS, Kehlet $H$. Consequences of persistent pain after lung cancer surgery: a nationwide questionnaire study. Acta Anaesthesiol Scand 2011; 55: 60-8.

21. Wildgaard K, Ringsted TK, Hansen HJ, Petersen RH, Werner $M U$, Kehlet $H$. Quantitative sensory testing of persistent pain after video-assisted thoracic surgery lobectomy. $\mathrm{Br} \mathrm{J}$ Anaesth 2012; 108: 126-33.

22. Andersen $K G$, Kehlet $H$. Persistent pain after breast cancer treatment: a critical review of risk factors and strategies for prevention. J Pain 2011; 12: 725-46.

23. Are $C$, Rajaram $S$, Are $M$, et al. A review of global cancer burden: trends, challenges, strategies, and a role for surgeons. J Surg Oncol 2013; 107: 221-6.

24. Kehlet H, Rathmell JP. Persistent postsurgical pain: the path forward through better design of clinical studies. Anesthesiology 2010; 112: 514-5.

25. McCarthy M Jr, Jonasson O, Chang CH, et al. Assessment of patient functional status after surgery. J Am Coll Surg 2005; 201: $171-8$
26. Ringsted TK, Wildgaard $K$, Kreiner $S$, Kehlet $H$. Pain-related impairment of daily activities after thoracic surgery: a questionnaire validation. Clin J Pain 2013; 29(9): 791-9.

27. VanDenKerkhof EG, Hopman WM, Goldstein DH, et al. Impact of perioperative pain intensity, pain qualities, and opioid use on chronic pain after surgery: a prospective cohort study. Reg Anesth Pain Med 2012; 37: 19-27.

28. Young EE, Lariviere WR, Belfer I. Genetic basis of pain variability: recent advances. J Med Genet 2012; 49: 1-9.

29. Buchheit T, Van de Ven T, Shaw A. Epigenetics and the transition from acute to chronic pain. Pain Med 2012; 13: 1474-90.

30. Werner MU, Mjobo HN, Nielsen PR, Rudin A. Prediction of postoperative pain: a systematic review of predictive experimental pain studies. Anesthesiology 2010; 112: 1494-502.

31. Srikandarajah S, Gilron I. Systematic review of movementevoked pain versus pain at rest in postsurgical clinical trials and meta-analyses: a fundamental distinction requiring standardized measurement. Pain 2011; 152: 1734-9.

32. Dworkin RH, McDermott MP, Raja SN. Preventing chronic postsurgical pain: how much of a difference makes a difference? Anesthesiology 2010; 112: 516-8.

33. VanDenKerkhof EG, Peters ML, Bruce J. Chronic pain after surgery: time for standardization? A framework to establish core risk factor and outcome domains for epidemiological studies. Clin J Pain 2013; 29: 2-8.

34. Higgins JP, Altman DG, Gotzsche PC, et al. Cochrane Bias Methods Group; Cochrane Statistical Methods Group. The Cochrane Collaboration's tool for assessing risk of bias in randomised trials. BMJ 2011; 343: d5928.

35. Bordet T, Pruss RM. Targeting neuroprotection as an alternative approach to preventing and treating neuropathic pain. Neurotherapeutics 2009; 6: 648-62.

36. Ellis A, Bennett DL. Neuroinflammation and the generation of neuropathic pain. Br J Anaesth 2013; 111: 26-37.

37. Martinez V, Szekely B, Lemarie J, et al. The efficacy of a glial inhibitor, minocycline, for preventing persistent pain after lumbar discectomy: a randomized, double-blind, controlled study. Pain 2013; 154: 1197-203. 